\title{
Antibacterial Effects of Vitamin E: in Vitro Study
}

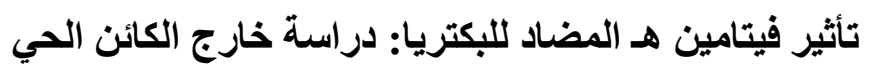
Dalia Abd Al Kader Al-Salih Fitua M. Aziz Bahir Abdul Razzaq Mshimesh
Muhanad T. Jehad*
College of Pharmacy/ Al Mustansiriya University
*Medical legal institute
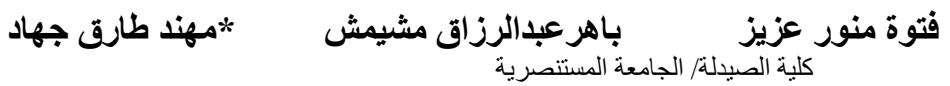

\section{Abstract}

Overuse of antibiotics has become the major factor for the emergence and dissemination of multi-drug resistant strains of several groups of microorganisms and this lead to search for agents that may have antibacterial effects. Vitamin $E$ emerged as an essential, fat-soluble nutrient in the human body and it is essential, because the body cannot manufacture its own vitamin $E$, so foods and supplements must provide it. The aim of the present study was to evaluate the effect of vitamin $E$ against pathogenic bacteria. Gram positive and gram negative bacteria were selected as the test microorganisms based on their importance in infections. In this study vitamin $E$ used in four concentrations $(50,100,200,400) \mathrm{IU} / \mathrm{ml}$. The agar diffusion method was used to determine antibacterial activity. Results showed that gram negative bacteria were shown to be more resistant than gram positive bacteria. The resistance of gram negative bacteria towards antibacterial substances may be related to lipopolysaccharides in their outer membrane.

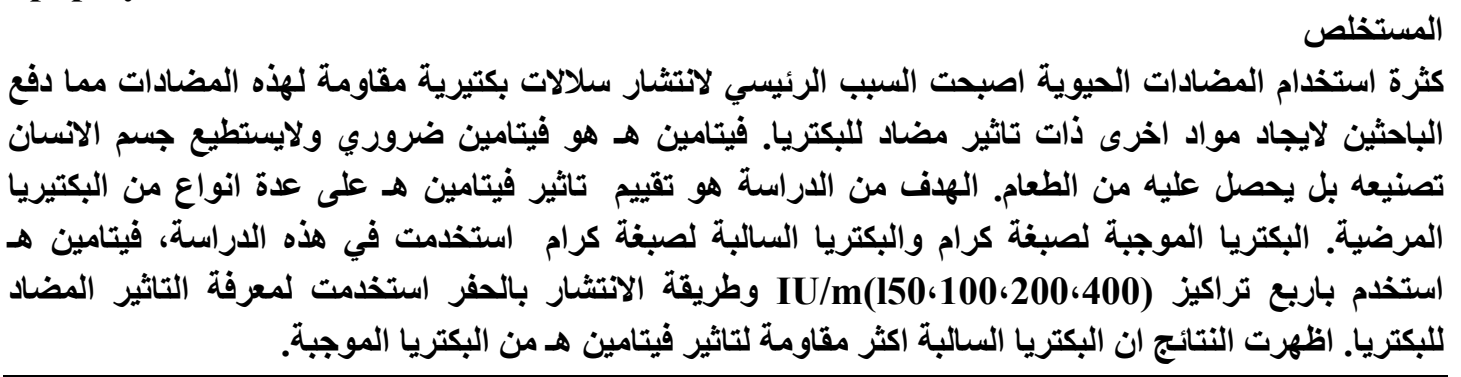

\section{Introduction}

Vitamin E is a term that comprises a family of lipophilic anti-oxidants: the tocopherols. Tocopherols contain a chromanol ring and an isoprenoid chain [1] Vitamin E emerged as an essential, fat-soluble nutrient in the human body and it is essential, because the body cannot manufacture its own vitamin E, so foods and supplements must provide it [2]. It is well established that vitamin $\mathrm{E}$ is a major antioxidant in cellular membranes[3] and protects membrane lipids from peroxidation by scavenging peroxyl, oxygen and superoxide anion radicals[4,5]. Vitamin $\mathrm{E}$ has also been shown to have prominent antiinflammatory effects $[3,6,7]$. Available evidence suggests that the beneficial effects of supplemental Vitamin $\mathrm{E}$ are on immune function and related diseases. Vitamin $\mathrm{E}$ is perhaps one of the most studied nutrients in relation to its immunoregulatory effect. Results from animal and human studies indicate that vitamin E deficiency impairs both humoral and cell-mediated immune functions while supplementation with Vitamin $\mathrm{E}$ above the recommended levels has been shown to enhance immune response and to be associated 
with increased resistance against several pathogens [8]. Furthermore, it has been extensively demonstrated in animal studies that Vitamin $\mathrm{E}$ has neither mutagenic, nor carcinogenic, or teratogenic properties. Several reports show that vitamin E has a very low toxicity in humans, and that even a dosage greater than $1000 \mathrm{mg} /$ day (1000 IU) is considered to be safe. Therefore, a daily dosage of (100-300)mg of Vitamin E can be considered harmless from a toxicological point of view [1]. Several investigations have demonstrated that vitamin E significantly enhances immune functions in humans, especially in the elderly. Animal studies as well as recently completed clinical trials strongly suggest that this effect of Vitamin $\mathrm{E}$ is associated with reduced risk of acquiring infections, particularly upper respiratory tract infections in elderly [8]. [9] reported that improvement in a 14-year-old boy with epidermolysis bullosa dystrophica treated with oral Vitamin E succinate in daily doses ranging as high as $6000 \mathrm{IU}$. This therapy was based on a report by [10] of a salutary effect of Vitamin E on leg ulcers and one by [11] at the Canadian Medical Association annual meeting of improvement in epidermolysis bullosa following the use of vitamin $\mathrm{E}$.

The aim of the present study was to evaluate the effect of vitamin $\mathrm{E}$ against pathogenic bacteria. Gram positive and gram negative bacteria were selected as the test microorganisms based on their importance in infections.

\section{Materials and methods}

This study was done in microbiology and pharmacology labs in college of pharmacy/Al Mustansiriya University, in a period between October, 2010 to March/2011. All bacterial strains used in this study were clinical strains, they are: Staphylococcus aureus, Staphylococcus epidermidis, Escherichia coli, Proteus spp., Klebsiella spp., Pseudomonas aeruginosa and Enterobacter spp. In this study vitamin E dissolved in propylene glycol in order to obtain the final concentrations $(50,100,200,400) \mathrm{IU} / \mathrm{ml}$. The agar diffusion method was used to determine antibacterial activity $[12,13]$. Sterile filter paper discs were prepared to a diameter of $6 \mathrm{~mm}$ and sterilized in oven at $\left(170^{\circ} \mathrm{c}\right.$ for $\left.2 \mathrm{hrs}\right)$. The culture medium was inoculated with one of tested bacteria suspended in nutrient broth. Discs were soaked with 20 microlitre of vitamin E and placed on the inoculated agar.

Erythromycin $(15 \mu \mathrm{g} / \mathrm{disc})$, cephalexin $(30 \mu \mathrm{g} / \mathrm{disc})$, clindamycin $(2 \mu \mathrm{g} / \mathrm{disc})$ and tetracycline $(30 \mu \mathrm{g} / \mathrm{disc})$ were used as positive control. The plates were then incubated at $37^{\circ} \mathrm{c}$ for $24 \mathrm{hrs}$. After incubation, the antibacterial activity of vitamin E was evaluated by measuring the diameter of inhibition zone in millimeter; the sample was tested in duplicate.

\section{Results}

All seven types of bacteria used in this study were resistant to erythromycin ( $15 \mu \mathrm{g} / \mathrm{disc})$, cephalexin $(30 \mu \mathrm{g} /$ disc $)$, clindamycin $(2 \mu \mathrm{g} /$ disc $)$ and Tetracycline $(30 \mu \mathrm{g} /$ disc $)$ as showed in Table (1) 
Table (1): The resistance of seven types of bacteria

\begin{tabular}{|c|c|c|c|c|}
\hline \multicolumn{2}{|c|}{ Bacteria } & \multicolumn{3}{|c|}{$\begin{array}{c}\text { Mean of Zone of inhibition (mm) of } \\
\text { antibiotics used }\end{array}$} \\
\hline & $\begin{array}{l}\text { Erythromycin } \\
(15 \mu \mathrm{g} / \text { disc })\end{array}$ & $\begin{array}{l}\text { Cephalexin } \\
(30 \\
\mu g / d i s c)\end{array}$ & $\begin{array}{l}\text { Clindamycin } \\
(2 \mu \mathrm{g} / \mathrm{disc})\end{array}$ & $\begin{array}{l}\text { Tetracycline } \\
(30 \mu g / d i s c)\end{array}$ \\
\hline Staph. aureus & - & - & - & - \\
\hline $\begin{array}{l}\text { Staph. } \\
\text { epedermidis }\end{array}$ & - & - & - & - \\
\hline E.coli & - & - & - & - \\
\hline Proteus spp. & - & - & - & - \\
\hline Klebsiella spp. & - & - & - & - \\
\hline $\begin{array}{l}\text { Pseudomonas } \\
\text { aeruginosa }\end{array}$ & - & - & - & - \\
\hline Enterobacter spp. & - & - & - & - \\
\hline
\end{tabular}

Note : ( - indicates no inhibition)

The results showed that the propylene glycol which was used as a solvent to Vitamin E had no antibacterial activity. The effect of four concentrations of Vitamin $\mathrm{E}$ on different pathogens showed in Table (2)

Table (2): Antibacterial activity of Vitamin $\mathrm{E}$ on different pathogens

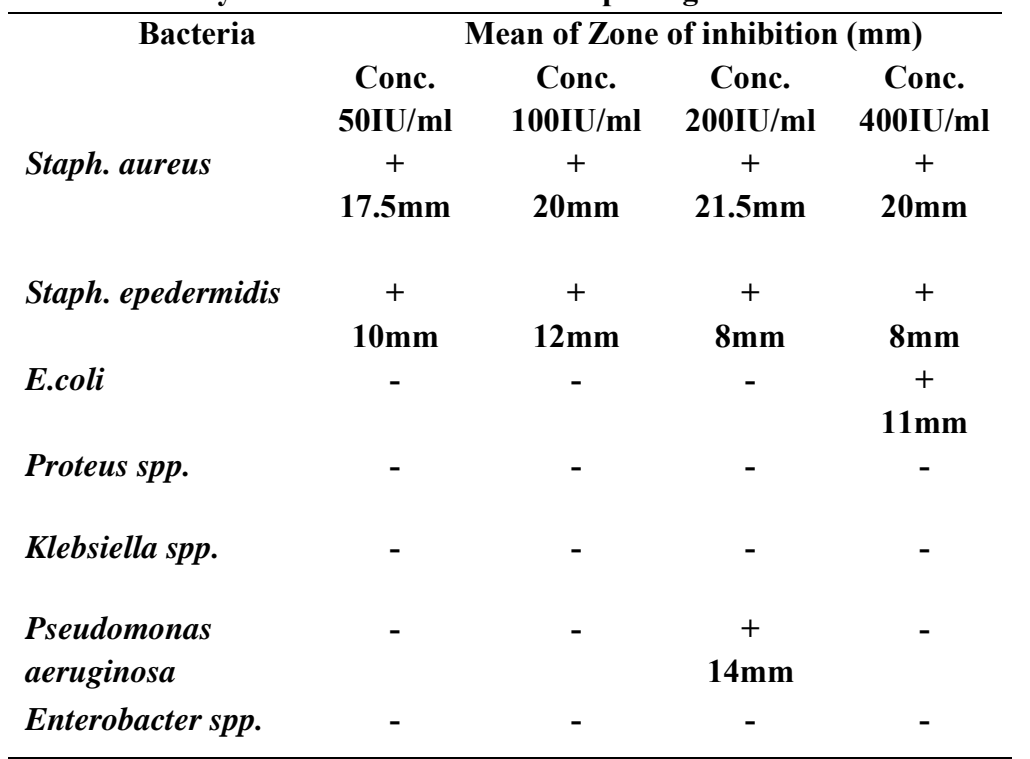

Note: (- indicates no inhibition ; + indicates inhibition)

Regarding the effect of vitamin E $(50 \mathrm{IU} / \mathrm{ml})$ on mean of zone of inhibition of different pathogens; the mean of zone of inhibition of staph. aureus was $17.5 \mathrm{~mm}$ figure $(1,5)$ and for staph. epidermidis was $10 \mathrm{~mm}$ figure $(1,6)$. klebsiella, E.coli, Enterobacter spp., Proteus spp. and pseudomonas aeruginosa were resistant to this conc. of vitamin E figure (1). 
Figure (1): Effect of Vitamine E $50 \mathrm{IU} / \mathrm{ml}$ on Mean of Zone of Inhibition of Different pathogens

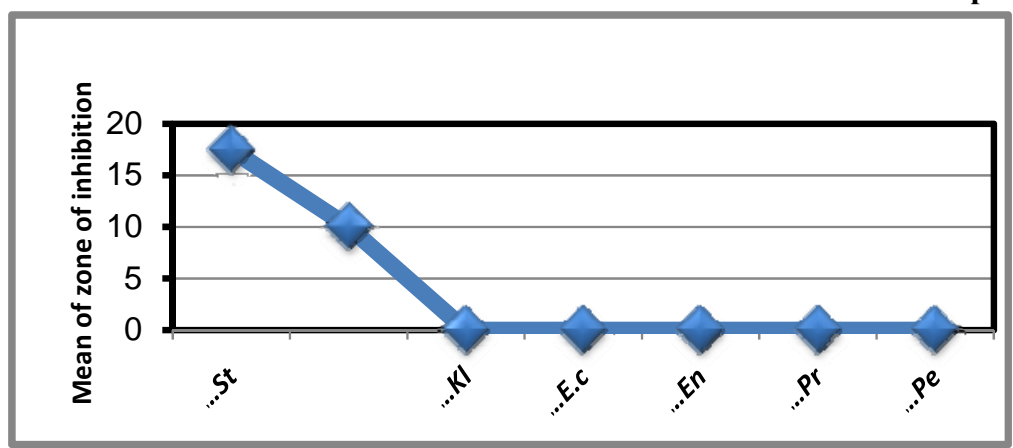

Regarding the effect of vitamin E (100 IU $/ \mathrm{ml})$ on mean of zone of inhibition of different pathogens; the mean of zone of inhibition of staph. aureus was $20 \mathrm{~mm}$ figure $(2,5)$ and for staph.epidermidis was $12 \mathrm{~mm}$ figure $(2,6)$. klebsella, E.coli, Enterobacter spp., Proteus spp. and pseudomonas aeruginosa were resistant to this conc. of vitamin E figure (2).

Figure (2): Effect of Vitamine E $100 \mathrm{IU} / \mathrm{ml}$ on Mean of Zone of Inhibition of Different pathogen

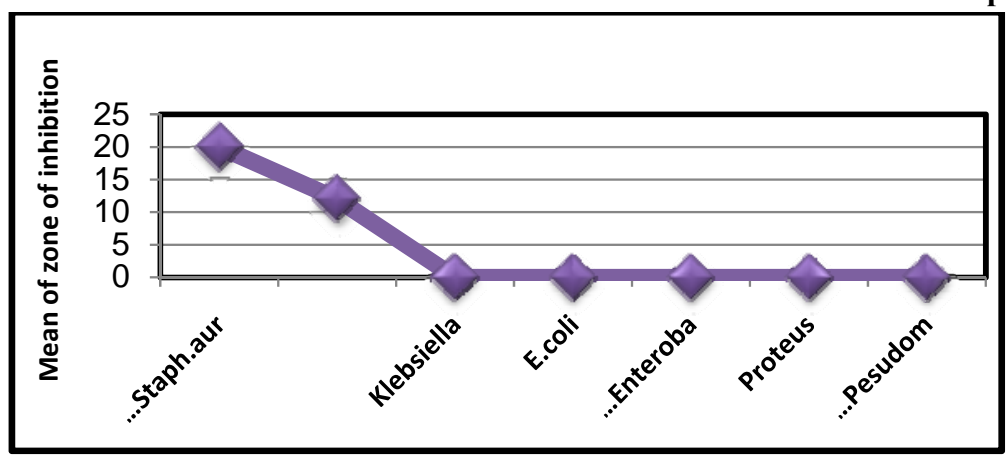

Regarding the effect of vitamin E $(200 \mathrm{IU} / \mathrm{ml})$ on mean of zone of inhibition of different pathogens; the mean of zone of inhibition of staph. aureus was $21.5 \mathrm{~mm}$ figure $(3,5)$ and for staph.epidermis was $8 \mathrm{~mm}$ figure $(3,6)$. pseudomonas aeruginosa was susceptible and mean of zone of inhibition was $14 \mathrm{~mm}$. klebsella, E.coli, Enterobacter spp. and Proteus spp. were resistant to this conc. of vitamin E figure (3).

Figure (3): Effect of Vitamin E $200 \mathrm{IU} / \mathrm{ml}$ on Mean of Zone of Inhibition of Different pathogen

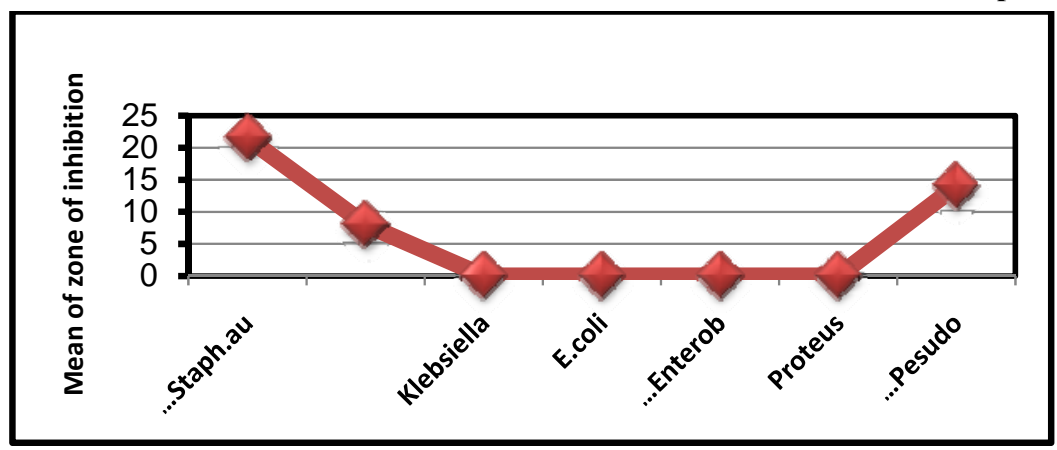

Regarding the effect of vitamin E $(400 \mathrm{IU} / \mathrm{ml})$ on mean of zone of inhibition of different pathogens; the mean of zone of inhibition of staph. aureus was $20 \mathrm{~mm}$ figure $(4,5)$, for staph.epedermis was $8 \mathrm{~mm}$ figure $(4,6)$ and for E.coli was $11 \mathrm{~mm}$ figure $(4,8)$. klebsella, Enterobacter spp., Proteus spp. and pseudomonas aeruginosa were resistant to this conc. of vitamin E figure (4). 
Figure (4): Effect of Vitamin E $400 \mathrm{IU} / \mathrm{ml}$ on Mean of Zone of Inhibition of Different pathogen

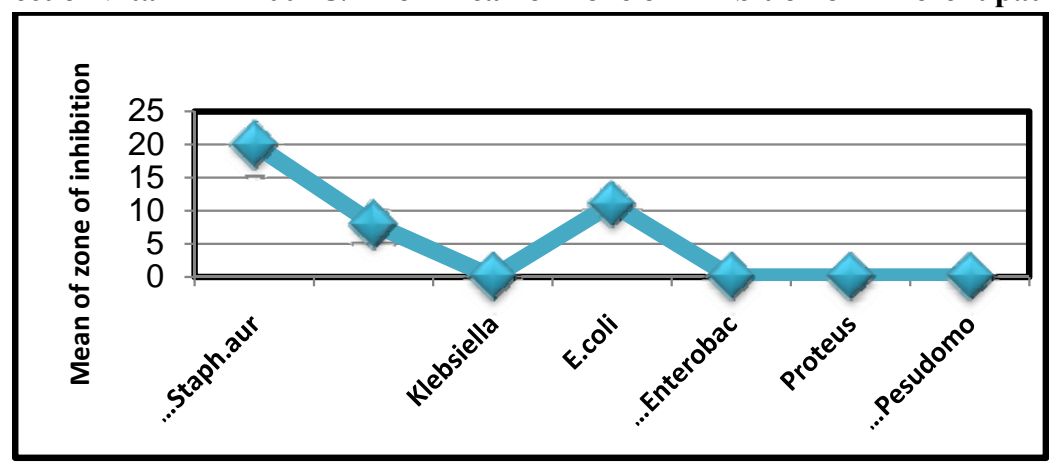

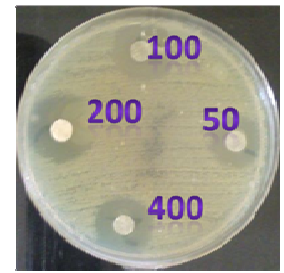

Figure (5): Effect of different conc. of Vitamin E on Staph. aureus

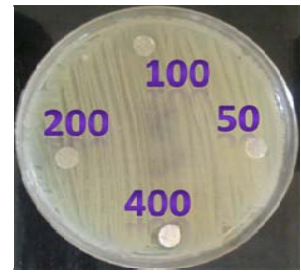

figure (7): Effect of different conc. of Vitamin E on Pseudomonas aeruginosa

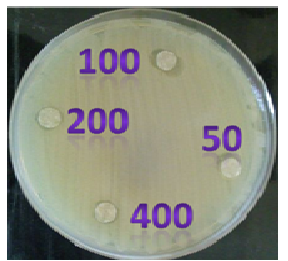

figure (6): Effect of different conc. of vitamin E on Staph. epidermidis

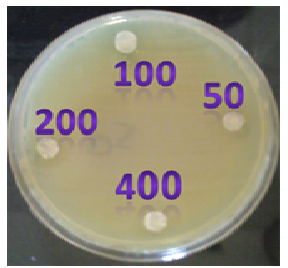

figure (8): Effect of different conc. of Vitamin E on E. coli

\section{Discussion}

Antibiotics provide the main basis for the therapy of microbial (bacterial and fungal) infections. Since the discovery of these antibiotics and their uses as chemotherapeutic agents there was a belief in the medical fraternity that this would lead to the eventual eradication of infectious diseases. However, overuse of antibiotics has become the major factor for the emergence and dissemination of multidrug resistant strains of several groups of microorganisms [14] and this lead to search for agents that may have antibacterial effects.

In this study, seven types of bacteria were used, all of them were resistant to antibacterial agents used [erythromycin $(15 \mu \mathrm{g} / \mathrm{disc})$, cephalexin $(30 \mu \mathrm{g} / \mathrm{disc})$, clindamycin $(2 \mu \mathrm{g} / \mathrm{disc})$ and Tetracycline $(30 \mu \mathrm{g} /$ disc) $)$ as showed in table (1) and using Vitamin E in conc. of $(50,100,200,400) \mathrm{IU} / \mathrm{ml}$ give positive results with staph. aureus and staph.epedermidis. Pseudomonas aeruginosa was sensitive to $200 \mathrm{IU} / \mathrm{ml}$ while E.coli was sensitive to 400 $\mathrm{IU} / \mathrm{ml}$. Other types of bacteria were resistant to all conc. of vitamin E used in this study. The result showed that gram negative bacteria were shown to be more resistant than gram positive bacteria. The resistance of gram negative bacteria towards antibacterial substances may be related to lipopolysaccharides in their outer membrane [15]. 
As mentioned with previous studies, Vitamin $\mathrm{E}$ is a powerful antioxidant and a scavenger of hydroxyl radicals, and it has been shown to have anti-inflammatory activities in tissues [16]. Factors that improve antioxidant status may modulate the immune function; reduce tissue damage and bacterial colonization [17].

Most of the animal studies that investigated the effect of Vitamin E on infectious diseases reported a protective effect despite the variations in the dose and duration of the supplementation, infectious organisms involved, and route of administration. Only a limited number of studies have investigated the effect of vitamin $\mathrm{E}$ on resistance against infections in humans [8]. In a study of the effect of Vitamin E on secondary bacterial infection after influenza infection in young and old mice which done in 2004, the result was that Vitamin E supplementation abolished the priming effect of influenza infection on S.aureus and the researchers concluded that vitamin E may exert its effect by number of mechanisms, including reducing reactive oxygen species (ROS), decreasing proinflammatory cytokines and adhesion molecule expression and production, increasing antioxidant and antimicrobial activity [17].

\section{Conclusion}

All seven types of bacteria used in this study were resistant to erythromycin ( $15 \mu \mathrm{g} / \mathrm{disc})$, cephalexin $(30 \mu \mathrm{g} / \mathrm{disc})$, clindamycin $(2 \mu \mathrm{g} / \mathrm{disc})$ and Tetracycline $(30 \mu \mathrm{g} / \mathrm{disc})$.Vitamin $\mathrm{E}$ in concentrations used in this study had an in vitro antibacterial effect against some of these types of bacteria and other types were resistant.

After progressive survey in previous literature, we did not find any in vitro study about antibacterial effect of vitamin $\mathrm{E}$ on these pathogens.

\section{Recommendation}

Further studies may be required to establish vitamin $\mathrm{E}$ antibacterial activity and to study mechanism of action of vitamin $\mathrm{E}$ as antibacterial agent.

\section{References}

1. Serafini, M. 2000. Dietary vitamin $E$ and $T$ cell-mediated function in the elderly: effectiveness and mechanism of action. Int. J. Devl Neuroscience. 18: 401-410.

2. Sen, CK., Khanna, S. and Roy, S. 2006. Tocotrienols: Vitamin E beyond tocopherols. Life Sci. 78(18): 2088- 2098.

3. Mirbagheri, SA, Nezami, BG, Assa, S. 2008. Rectal administration of d-alpha tocopherol for active ulcerative colitis: a preliminary report. World J Gastroenterol. 14:5990-5.

4. Burton, GW., Joyce, A. and Ingold, KU. 1982. First proof that vitamin E is Major lipid-soluble, chain-breaking antioxidant in human blood plasma. Lancet. 2:327.

5. Isozaki, Y., Yoshida, N., Kuroda, M. 2006. Effect of a novel water-soluble vitamin E derivative as a cure for TNBS-induced colitis in rats. Int J. Mol Med. 17:497-502.

6. Fox, ES., Brower, JS., Bellezzo, JM. 1997. N-acetylcysteine and alphatocopherol reverse the inflammatory response in activated rat Kupffer cells. J Immunol.158:541823.

7. Yoshida, N., Yoshikawa, T., Manabe, H. 1999. Vitamin E protects against polymorphonuclear leukocyte-dependent adhesion to endothelial cells. J Leukoc Biol. 65:757-63.

8. Meydani, SN., Han, SN. and Hamer, DH. 2004. Vitamin E and respiratory infection in the elderly. Ann. N.Y. Acad. Sci. 1031: 214-222. 
9. Wilson, HD. 1964.Treatment of epidermolysis bullosa by alpha-tocopherol. Can Med Assoc J. 90: 1315.

10. Shute, EV. Summ Shute Inst. 1960. 12: 45.

11. Price, I. 1962. Interesting new therapy of epidermolysis bullosa. Report delivered at Can Med Assoc annual meeting.

12. NCCLS. Performance standards for antimicrobial disc susceptibility tests, $4^{\text {th }}$ ed. Approved standard M2-A4. NCCLS, villanova, pa. 1990.

13. NCCLS. Performance standards for antimicrobial susceptibility testing. Third informational supplement M100-S3. NCCLS, villanova, pa. 1991.

14. Khan, R., Islam, B., Akram, M. 2009. Antimicrobial activity of five herbal extracts against multi drug resistant (MDR) strains of bacteria and fungus of clinical origin. Molecules. 14:586-597.

15. Gao, Y., Belkun, M.J. and M. stiles. 1999. The outer membrane of gram negative bacteria inhibits antibacterial activity of Brochacin C. Applied Environ. Microbial. 65:4329-4333.

16. Tahan, G., Aytac, E., Aytekin, H. 2011. Vitamin E has a dual effect of antiInflammatory and antioxidant activities in acetic acid-induced ulcerative colitis in rats. Can J Surg. 54(5): 333-338.

17. Gay, R., Han, SN. Marko, M. 2004.The effect of Vitamin E on secondary bacterial infection after influenza infection in young and old mice. Ann. N.Y. Acad. Sci. 1031: 418-421. 